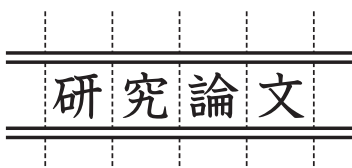

\title{
木質バイオマスの粉砕エネルギーに及ぼす樹種および粉砕方式の影響 \\ Effect of Tree Species and Comminution Method on Comminution Energy of Woody Biomass
}

\author{
西 健 治**大政 光 史 ${ }^{* *}$ ・廣川敬 康** \\ 澤井 徹 ${ }^{* *} \cdot$ 渋江唯 司**・梶本武志*** \\ Kenji NISHI, Mitsushi OHMASA, Noriyasu HIROKAWA, Toru SAWAI, Tadashi SHIBUE and Takeshi KAJIMOTO
}

(Received January 12, 2012)

\begin{abstract}
In order to reduce the emission of greenhouse gases, much attention has been focused on energy utilization of biomass in recent years. The promotion of the utilization of domestic woody biomass contributes not only to the improvement of energy selfsufficiency, but also to the environmental protection of forests and undeveloped woodlands near populated areas or satoyamas in Japan. Typical woody biomass derived from Japanese forests and satoyamas are Japanese Cedar and Konara. When woody biomass is utilized as biomass fuel, it is important to examine the energy consumptions for pretreatments such as comminution and reforming. In this study, using Konara, Japanese Cedar, and Balsa, the effects of tree species, comminution methods, and semicarbonization of the woody biomass on comminution energy are investigated. The results obtained in this study are as follows. (1) In the case that water content is less than a fiber saturation point, the comminution energy for three species is expressed as a function of water content. In the case that water content exceeds a fiber saturation point, comminution energy for three species is expressed as a function of density. The comminution energy can be estimated by using the present empirical equations within $\pm 50 \%$ accuracy. (2) Regarding the comminution property of semi-carbonized woody biomass, for the wood region, the empirical equations of work index depend on the comminution methods regardless of tree species and sieve of screen. For the semi-carbonized and carbonized regions, the empirical equation of work index is presented regardless of tree species, comminution methods, and sieve of screen. The comminution energy can be estimated by using the present empirical equations within $\pm 60 \%$ accuracy.
\end{abstract}

Key Words: Woody Biomass, Comminution Energy, Semi-carbonization, Density of Tree Species

\section{1. 緒言}

再生可能エネルギーへの関心が高められていく中、様々 な分野でバイオマスに関する政策が打ち出されている。平 成 23 年 11 月に「電気事業者による再生可能エネルギー電 気の調達に関する特別措置法案」が国会で成立し、平成 24 年 7 月から「再生可能エネルギーの固定価格買取制度」が 施行される1”。この制度は再生可能エネルギーによって発 電された電気を、一定期間、固定価格で電気事業者が買い 取ることを義務付けるとともに、再生可能エネルギーを買 い取る費用を、国民が電気料金の一部として負担する。こ の制度により国民がバイオマスをはじめとする再生可能エ ネルギーについて理解を深め、普及の後押しになっていく と考えられる。

今後利活用を促進させていくべき国内のバイオマス資源
の一つとして、農林業に由来する国産の未利用バイオマス が挙げられて抢り、「バイオマスニッポン総合戦略」でも 利用拡大の方針が提示されている ${ }^{2)}$ 。国産資源の利活用は、 二酸化炭素の排出削減のみならず、エネルギー自給率の向 上、森林保全、農林業の活性化とも結びうき、多くの意義 を有している。とりわけ、森林保全は火急の課題とされて いる。これは、林業採算性の低下から森林所有者の林業離 れが進み、森林資源が十分活用されないばかりか、必要な 施業が行われず、森林のもつ公益的機能の発揮にも支障を 来すことが危惧されていることによる。このため、農林水 産省は、森林の有する多面的機能の持続的発揮と林業・木 材産業の再生を図りつつ、木材の利用を通じた低炭素社会 の構築を図ることを目的に、平成 21 年 12 月に「森林・林 業再生プラン」を策定した ${ }^{3}$ 。ささらに、平成 22 年 6 月 18 日に閣議決定された「新成長戦略〜「元気な日本」復活の

* 近畿大学大学院生物理工学研究科（广 649-6493 和歌山県紀の川市西三谷 930）

Graduate school of Biology-Oriented Science and Technology, Kinki University, (930 Nishimitani, Kinokawa, Wakayama 649-6493, Japan)

* * 近畿大学生物理工学部（

School of Biology-Oriented Science and Technology, Kinki University, (930 Nishimitani, Kinokawa, Wakayama 649-6493, Japan)

****和歌山県工業技術センター（～６49-6261 和歌山市小倉 60）

Industrial Technology Center of Wakayama Prefecture, (Ogura, Wakayama 649-6261, Japan) 
シナリオ〜」は、森林・林業再生プランを国家戦略プロジェ クトの一つと位置付け選定した ${ }^{4)}$ 。森林・林業に関する施 策が国家的な戦略に位置付けられることはこれまでにな かったことで、森林バイオマスが今後重要な位置を占めて いくと考えられる。

一方、豊富に存在する森林バイオマスは、山林からの搬 出に多大なエネルギーを要し、安定供給の点で課題を残し ている。そこで著者らは里山の木質資源に着目した。里山 は産出地が需要地に近接しているため、林地搬出のエネル ギー損失を大幅に回避できる。また里山の中核を成す二次 林は森林面積の $30 \%$ を占め ${ }^{5)}$ 、里山の木質資源生長量は約 3000 万 $\mathrm{t}-\mathrm{C} /$ 年にもなり ${ }^{2}$ 、豊富な資源を有している。平成 22 年 10 月には愛知県名古屋市で「生物多様性条約第 10 回 締約国会議」が開催され、「SATOYAMA イニシアティブ」 が推進された7。このように世界各地で里山のような二次 的自然環境を改めて見直し、持続可能な関係の維持・再構 築を進め、自然共生社会の実現を目指す動きが始まってお り、里山に関する注目は高まりつつある。

著者らはこれまでスギ間伐材の利活用を念頭に置き、木 質系粉砕物燃料の可能性について研究を行ってきた ${ }^{8)}$ 。ウッ ドペレットの様な造粒を必要としない粉磱物燃料を地域資 源として利用し得る可能性を提示した。本研究では、里山 林の有効活用を念頭に置き、地域内のローカルバイオマス 資源として、里山の木質資源を粉砕物燃料として利用する ことを考える。国内の里山林の場合、コナラ、ブナといっ た広葉樹が主たる資源となって扔り 著者らがこれまで 研究対象にしてきた針葉樹のスギ間伐材とは特性が異なる 可能性がある。

本研究では、森林バイオマスの代表的な針葉樹である久 ギ間伐材、里山に賦存する代表的な広葉樹である高密度の コナラ材、木材資源の中で最も密度の低いバルサ材の 3 樹 種を対象に、粉砕物燃料製造のプロセスエネルギー評価に 扔いて重要となる粉砕特性を検討する。研究目的は以下の 2 点である。(1) 木質バイオマスの粉砕エネルギーに及ぼす 樹種、含水率、粉砕方式の影響を明らかにする。(2) 粉砕工 ネルギーの低減を図るために、半炭化処理を施した木質バ イオマスの粉研特性をそれぞれの樹種に対して明らかにす る。

\section{2. 実験装置及び方法}

\section{1 粉砕実験}

粉砕実験では、前報 ${ }^{8)}$ と同様、衝撃式のハンマーミルと 切削式のカッターミルを用いた。一般的に、前者は鉱物の ような硬い破砕物の粉砕に、後者は弾力のある破碎物の粉 砕に適している。両粉砕機共に所定の目開きのスクリーン を出口部に設置することで粉砕物の粒子径が調節可能とな る。スクリーンの目開きは $0.25 、 0.5 、 1 、 2 、 3 \mathrm{~mm}$ 、回転 数は $3000 \mathrm{rpm}$ に設定した。
1 実験当たり $5 \mathrm{~mm}$ 角に切り揃えた試料 $5 \mathrm{~g}$ を粉砕機に投 入し、粉砕機の負荷電流をサンプリング周波数 $1 \mathrm{~Hz}$ でパソ コンに取り込んだ。取り込んだデータから粉砕エネルギー $\mathrm{E}_{\mathrm{C}}[\mathrm{kJ} / \mathrm{kg}]$ を次式により算出した。

$$
E_{C}=\frac{e \cdot \cos \theta}{M} \int_{t_{1}}^{t_{2}}\left(I-I_{0}\right) \cdot d t
$$

ただし、I $[\mathrm{A}]$ は粉砕時の負荷電流、 $\mathrm{I}_{0}[\mathrm{~A}]$ は無負荷電流、 $\mathrm{e}[\mathrm{V}]$ は電圧、 $\mathrm{t}[\mathrm{s}]$ は時間である。 $\mathrm{M}[\mathrm{kg}]$ は粉砕投入質量と 排出質量の平均值を示す。eは $100 \mathrm{~V} 、 \cos \theta$ は 1 とした。 $\mathrm{t}$ 、 $\mathrm{t}_{2}$ は粉砕開始㧍よび終了時刻である。

\section{2 粉砕仕事指数}

粉砕エネルギーを予測するための実験相関式を提示す るために、Bond の法則 ${ }^{10)} に よ り$ 粉砕仕事指数を求めた。 Bond の法則は粒子に加えられたひずみエネルギーは粉砕 開始段階では粒子の体積に比例するが、粒子に亀裂が発生 した後には生成した破断面積に比例するとし、粉砕エネル ギー $\mathrm{E}_{\mathrm{C}}[\mathrm{kJ} / \mathrm{kg}]$ を次式で表している。

$$
E_{C}=W_{i}\left(\sqrt{\frac{100}{x_{p 0.8}}}-\sqrt{\frac{100}{x_{f 0.8}}}\right)
$$

ここで $\mathrm{x}_{\mathrm{f} 0.8}[\mu \mathrm{m}] 、 \mathrm{x}_{\mathrm{p} 0.8}[\mu \mathrm{m}]$ は粉砕前後の $80 \%$ 通過粒子径、 $\mathrm{W}_{\mathrm{i}}$ は粉砕仕事指数である。 $\mathrm{X}_{\mathrm{f} 0.8}$ は投入した試料の代表寸法 $(5$ $\mathrm{mm}) 、 \mathrm{x}_{\mathrm{p} 0.8}$ は粉砕により得られた砕成物を JIS Z 8815 にした がい 53〜2000 $\mu \mathrm{m}$ の範囲で分級することで得られた積算 分率から算出した。粉砕仕事指数は、計測された粉砕エネ ルギーと、 80 \% 通過粒子径から算出できる。

\section{3. 実験結果}

3.1 未改質木質バイオマスの粉砕エネルギー

3.1.1 実験試料

粉砕実験の試料にはスギ間伐材、コナラ材、バルサ材を 使用する。本節では未改質木質バイオマスの粉砕エネル ギーに及ぼす含水率の影響を検討するため、未改質の実験 試料を含水率 $\mathrm{w}=0 \sim 60 \%$ に調整する。な打、本研究の含 水率は湿潤べースに基づくものである。Fig.1 に含水率増加 による実験試料の密度変化を示す。絶乾状態に打いて、コ ナラ材、スギ間伐材、バルサ材の密度は 757、425、145 kg/ $\mathrm{m}^{3}$ であり、いずれの樹種も含水率増大に伴い密度は上昇す る。なお、コナラ材では含水率 $\mathrm{w}=60 \%$ の調整が困難であっ たため実験の対象外とした。

木材に含まれる水分には結合水と自由水の 2 種類がある。 自由水は木材の仮道管や道管などの細胞内腔中に液体の水 として存在する。結合水は木材を構成する高分子の水酸基 に水素結合で結びっく水分子である。木材が乾燥しても自 由水が減少する限りにおいては物理的性質はほとんど変化 しない。自由水が完全に蒸発し、結合水のみを含む $\mathrm{w}=20$ 


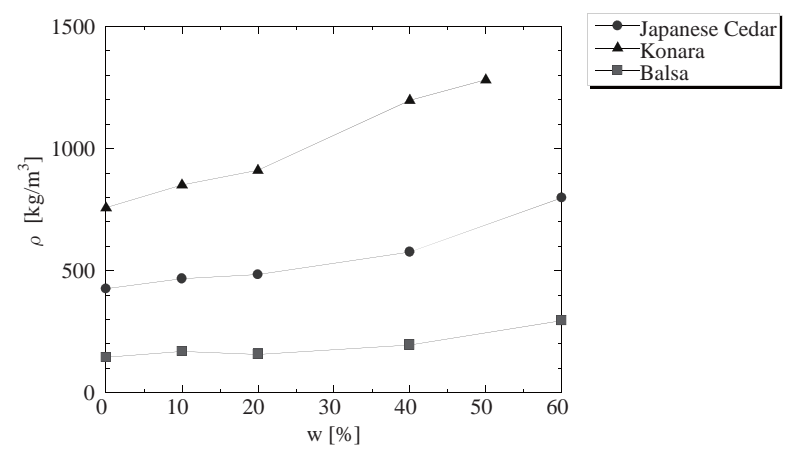

Fig.1 Variation of density with water content

〜 $30 \%$ の状態を繊維飽和点と呼ぶ。含水率が繊維飽和点 を下回ると化学的に結合している結合水が減少し、木材の 機械的性質は大きく変化することが知られている ${ }^{11)}$ 。

3.1 .2 粉砕エネルギーに及ぼす樹種・含水率・粉砕方式· スクリーンの影響

未改質のスギ間伐材、コナラ材、バルサ材の含水率 $\mathrm{w} に$ 対する粉砕エネルギー $\mathrm{E}_{\mathrm{C}}$ の変化をスクリーン $\mathrm{S}=3 \mathrm{~mm}$ を 一例として Fig.2に示す。図中、実線と破線は粉砕方式を、 記号の違いは樹種を表している。図中に示す一点鎖線は繊 維飽和点であり、繊維飽和点を境に粉砕エネルギーの特性 が異なっていることがわかる。繊維飽和点以下の含水率 $\mathrm{w}$ $\leqq 20 \%$ では、いずれの樹種も粉砕方式によらず $\mathrm{w}$ 減少と 共に $\mathrm{E}_{\mathrm{C}}$ は減少する。繊維飽和点以下の領域では、含水率の 減少により結合水が除去され木材が脆くなり機械的性質が 大きく変化したことで、粉砕エネルギーの減少が誘発され たと考えられる。また、この領域における樹種の差異を見 てみると、ハンマーミルでは密度の最も高いコナラ材が他 の樹種よりも若干高く、カッターミルでは密度の最も小さ いバルサ材が他の樹種よりも若干高くなっているものの、 樹種による差異はそれほど大きくなく、粉砕方式の差異が 顕著である。このことから、繊維飽和点以下では、それぞ れの粉砕方式に対して樹種に関係なく結合水の含有率から 一義的に粉砕エネルギーを決定できることになる。一方 $\mathrm{w}$ $\geqq 40 \%$ の繊維飽和点を超えた領域では、樹種により $\mathrm{E}_{\mathrm{C}}$ の 大きさと $\mathrm{E}_{\mathrm{C}}$ の $\mathrm{w}$ に対する変化が異なる。スギ間伐材の $\mathrm{E}_{\mathrm{C}}$ は、繊維飽和点とほぼ同じ值を有する。コナラ材の $\mathrm{E}_{\mathrm{C}}$ は、 繊維飽和点とほぼ同じ值あるいは $\mathrm{w}$ 増加に対して若干減 少する傾向も見られる。含水率の増加に対する粉砕エネル ギーの漸減は、粉砕試料単位質量当たりの木材割合が減少 したことが原因と考えられる。コナラ材とスギ間伐材では、 自由水が増しても $\mathrm{E}_{\mathrm{C}}$ への影響は小さい。バルサ材の $\mathrm{E}_{\mathrm{C}}$ は 繊維飽和点の $\mathrm{E}_{\mathrm{C}}$ より大きな值をとり、 $\mathrm{w}$ 増加に対してハン マーミルでは不変、カッターミルでは漸減する。バルサ材 の粉砕エネルギーが他樹種に比べ大きくなったのは、低密 度のため空隙が極めて多く、一部の空隙に自由水が含まれ

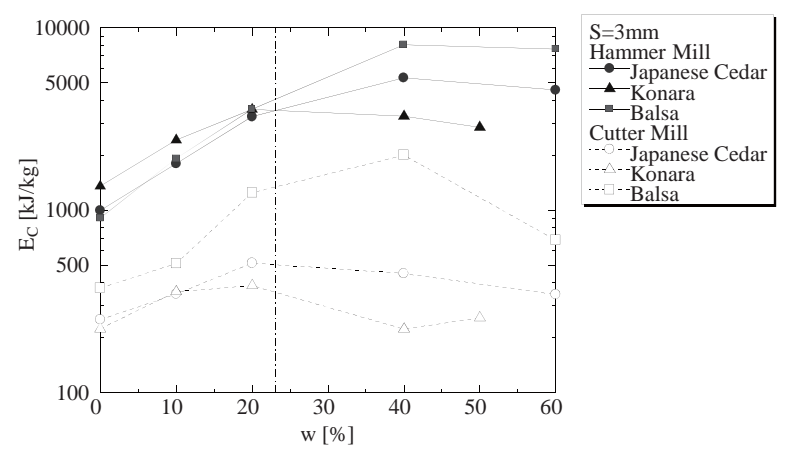

Fig.2 Effect of tree species and water content of woody biomass on comminution energy

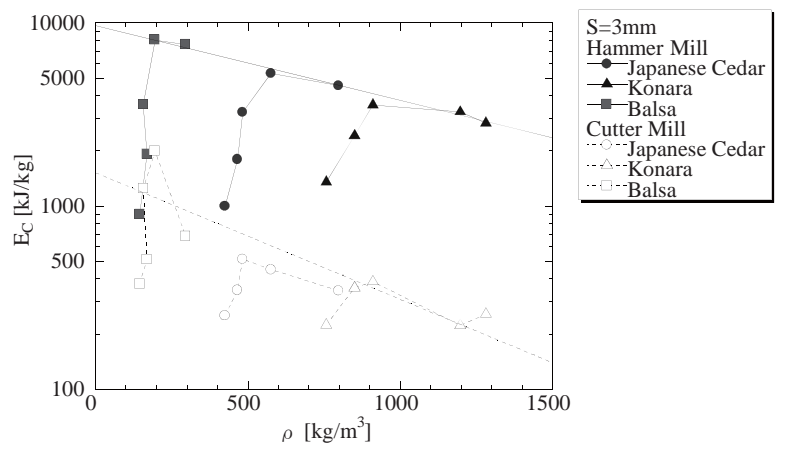

Fig.3 Effect of density of woody biomass on comminution energy

ているものの自由水を含まない空隙部分が衝撃吸収の役割 を果たしたためと考えられる。 $\mathrm{w} \geqq 40 \%$ における $\mathrm{E}_{\mathrm{C}}$ は樹 種の影響が顕著であり、同一の含水率に対しては、いずれ の粉砕方式でも、バルサ材、スギ間伐材、コナラ材の順で 粉砕エネルギーが変化する。

$\mathrm{w} \geqq 40 \%$ の繊維飽和点を超えた領域における樹種の影 響を整理するため、水分を含む試料密度 $\rho$ に対する粉砕工 ネルギー $\mathrm{E}_{\mathrm{C}}$ の変化を検討する。Fig.3 は $\rho$ に対する $\mathrm{E}_{\mathrm{C}}$ の 変化を表したものであり、図中のパラメータは Fig.2 と同 様である。各樹種のライン上の左端データから $\mathrm{w}=0 、 10$ 、 20、40、60\%の密度を示している。 $\mathrm{w} \geqq 40 \%$ の繊維飽和 点を超えた領域では、いずれの粉砕方式においても $\mathrm{E}_{\mathrm{C}}$ を $\rho$ に対して一義的に直線近似でき、罒中の実線、破線で示 す実験相関式で 3 樹種の $\mathrm{E}_{\mathrm{C}}$ を $\rho$ のみ関数として整理で きる。

Fig.4 は未改質のコナラ材の含水率 $\mathrm{w}$ に対する粉砕エネ ルギー $\mathrm{E}_{\mathrm{C}}$ の変化をスクリーン $\mathrm{S}$ 別に示す。図中、実線と 破線は粉砕方式を、記号の違いはスクリーンの目開き $\mathrm{S}$ を

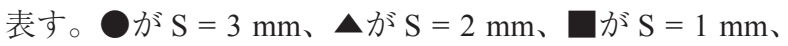
が $\mathrm{S}=0.5 \mathrm{~mm}$ 、が $\mathrm{S}=0.25 \mathrm{~mm}$ である。いずれの $\mathrm{S}$ に対 しても、ハンマーミルはカッターミルに比べ $\mathrm{E}_{\mathrm{C}}$ が大きく 


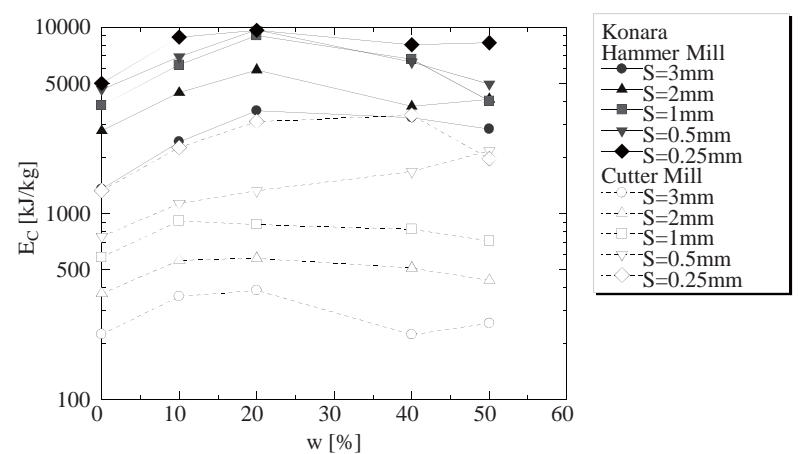

Fig.4 Effect of water content and screen of woody biomass on comminution energy

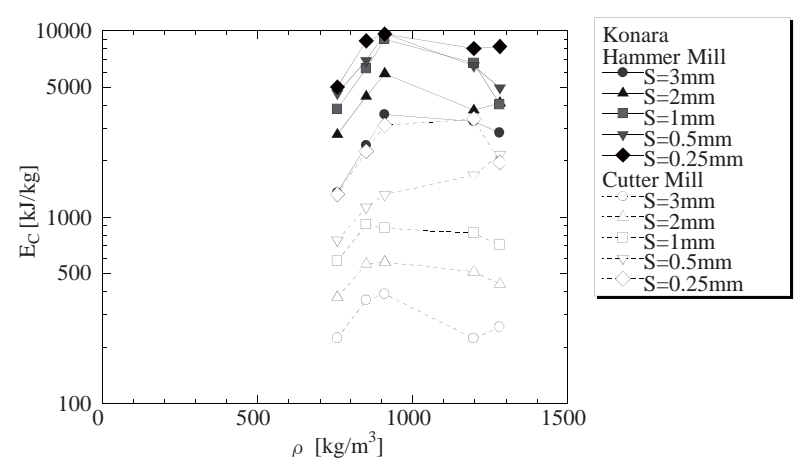

Fig.5 Effect of density and screen of woody biomass on comminution energy

なっている。また、いずれの粉砕方式も $\mathrm{S}$ 減少と共に $\mathrm{E}_{\mathrm{C}}$ は大きくなることがわかる。これは他の樹種についても同 様であった。

Fig.5 は未改質のコナラ材の密度 $\rho$ に対する粉砕エネル ギー $\mathrm{E}_{\mathrm{C}}$ の変化をスクリーン $\mathrm{S}$ 別に示す。図中、実線と破 線は粉砕方式を、記号の違いはFig.4 と同様である。いず れの粉砕方式も $\mathrm{S}$ 減少と共に $\mathrm{E}_{\mathrm{C}}$ は大きくなることがわか る。これは他の樹種についても同様であった。

3.1.3 Bond の法則による粉砕エネルギーの実験相関式

前節 3.1.2の結果より、繊維飽和点以下の含水率では粉砕 エネルギーを含水率の関数として、繊維飽和点以上の含水 率では粉砕エネルギーを密度の関数として表現し得ること が示された。本節では、この結果を受けて、繊維飽和点以 下と以上に分けて粉砕仕事指数の実験相関式を検討する。

Fig.6 は繊維飽和点以下の $\mathrm{w} \leqq 20 \%$ の試料の粉砕仕事指 数 $\mathrm{W}_{\mathrm{i}}$ を含水率 $\mathrm{w}$ に対して示したものである。図中のパラ メータは、樹種、粉砕方式、スクリーンを表す。それぞれ の粉砕方式に対して、樹種、スクリーンに関係なく式 (3)（図 中実線)、式 (4)（図中破線）に示す実験相関式が得られた。

$W_{i}=e^{8.57+0.07015 w}$ for Hammer mill in $\mathrm{w} \leqq 20 \%$

$W_{i}=e^{7.50+0.03820 w}$

for Cutter mill in $\mathrm{w} \leqq 20 \%$

Fig.7 は繊維飽和点を超えた $\mathrm{w} \geqq 40 \%$ の試料の粉砕仕事 指数 $\mathrm{W}_{\mathrm{i}}$ を密度 $\rho$ に対して示したものである。図中のパラ メータは、樹種、粉砕方式、スクリーンを表す。それぞれ の粉砕方式に対して、樹種、スクリーンに関係なく式 (5)（図 中実線)、式 (6)（図中破線）に示す実験相関式が得られた。

$W_{i}=e^{10.70-0.00058 \rho}$

for Hammer mill in $\mathrm{w} \geqq 40 \%$

$W_{i}=e^{9.84-0.00178 \rho}$

for Cutter mill in w $\geqq 40 \%$

Fig.6、Fig.7に示した $\mathrm{W}_{\mathrm{i}}$ の実験相関式より算出した粉砕 エネルギーの予測值 $\mathrm{E}_{\mathrm{Wi}}$ を粉砕エネルギーの実験值 $\mathrm{E}_{\mathrm{C}}$ と比 較した。比較結果を Fig.8に示す。 $\mathrm{W}_{\mathrm{i}}$ の実験相関式を用い ることで、 $\pm 50 \%$ の範囲で粉砕エネルギーの実験值を予測 することができる。

\section{2 半炭化木質バイオマスの粉砕エネルギー}

\section{2 .1 実験試料}

前報 ${ }^{8)}$ で示したように、半炭化処理を施すことで、固体 燃料の発熱量向上、粉砕エネルギーの低減、燃料輸送にか かわるエネルギーの低減が可能となる。本節では、半炭化 木質バイオマスの粉砕エネルギーに及ぼす半炭化改質の影 響を検討するため、スギ間伐材、コナラ材は $\mathrm{T}=150 \sim 500$ ${ }^{\circ} \mathrm{C}$ で、バルサ材は $\mathrm{T}=150 \sim 300{ }^{\circ} \mathrm{C}$ で 1 時間熱分解処理し た半炭化物を実験試料として用いた。熱分解は電気炉で昇 温速度 $30{ }^{\circ} \mathrm{C} / \mathrm{min}$ に設定し砂浴法 ${ }^{12}$ （酸化アルミニウムを 使用)により行った。半炭化物の含水率は $0 \%$ とする。なお、 $\mathrm{T}>300{ }^{\circ} \mathrm{C}$ のバルサ材の実験試料は、熱分解により崩壊し たため計測対象から外した。

Fig.9にスギ間伐材、コナラ材、バルサ材に拈ける半炭 化物の質量収率 $\mathrm{Y}_{\mathrm{M}}$ を熱分解温度 $\mathrm{T}$ に対して示す。質量収 率の值は絶乾状態における質量（ $\mathrm{T}=100{ }^{\circ} \mathrm{C} ）$ を基準として いる。パラメータは樹種別に○がスギ間伐材、ムがコナラ 材、ロがバルサ材を表している。いずれの樹種においても、 $\mathrm{T} \leqq 150{ }^{\circ} \mathrm{C}$ の $\mathrm{W}$ (木質) 領域では $\mathrm{Y}_{\mathrm{M}} \fallingdotseq 100 \% 、 200{ }^{\circ} \mathrm{C} \leqq \mathrm{T}$ $\leqq 400{ }^{\circ} \mathrm{C}$ の SC (半炭化) 領域では熱分解が進行し、揮発分 が放出され質量収率が $\mathrm{Y}_{\mathrm{M}} \doteqdot 30 \%$ にまで減少している。 $\mathrm{T}$ $\geqq 400{ }^{\circ} \mathrm{C}$ の (炭化) 領域では $\mathrm{Y}_{\mathrm{M}}$ が緩やかに減少してい ることがわかる。質量収率の変化に対する樹種の影響はほ とんど認められない。

Fig.10 に半炭化物の密度 $\rho$ を熱分解温度 Tに対して 示す。Fig.11に $\mathrm{T}=100{ }^{\circ} \mathrm{C}$ における絶乾状態密度 $\rho_{0}$ を基 準とした半炭化物の密度比を熱分解温度 $\mathrm{T} に$ 対して示す。 Fig.10では T が上昇するにつれ、いずれの樹種でも緩やか に $\rho$ が減少していることがわかる。これは、熱分解により 


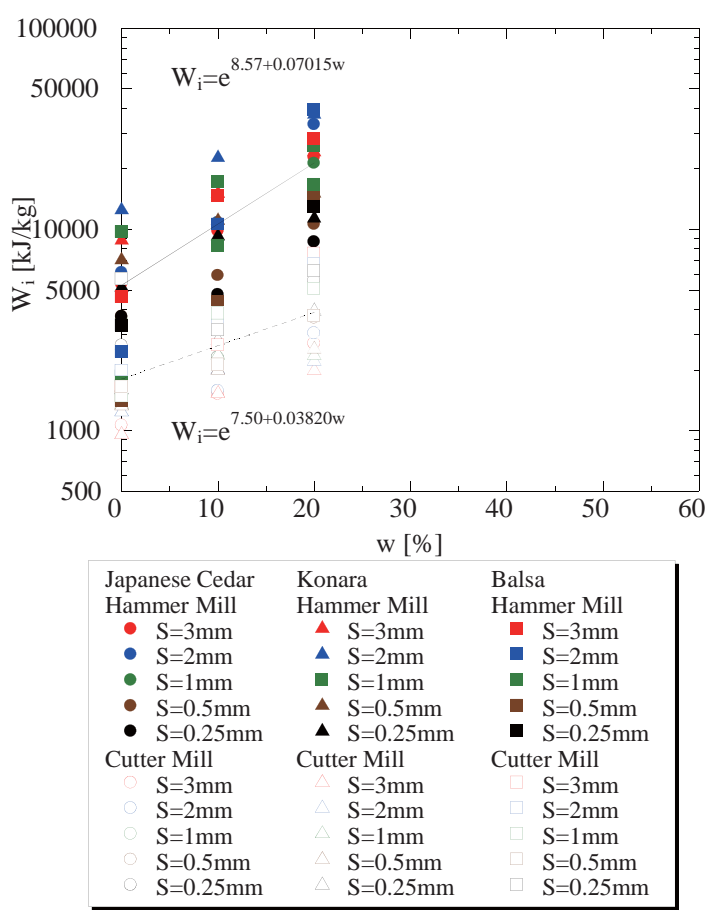

Fig.6 Empirical correlation of work index as a function of water content

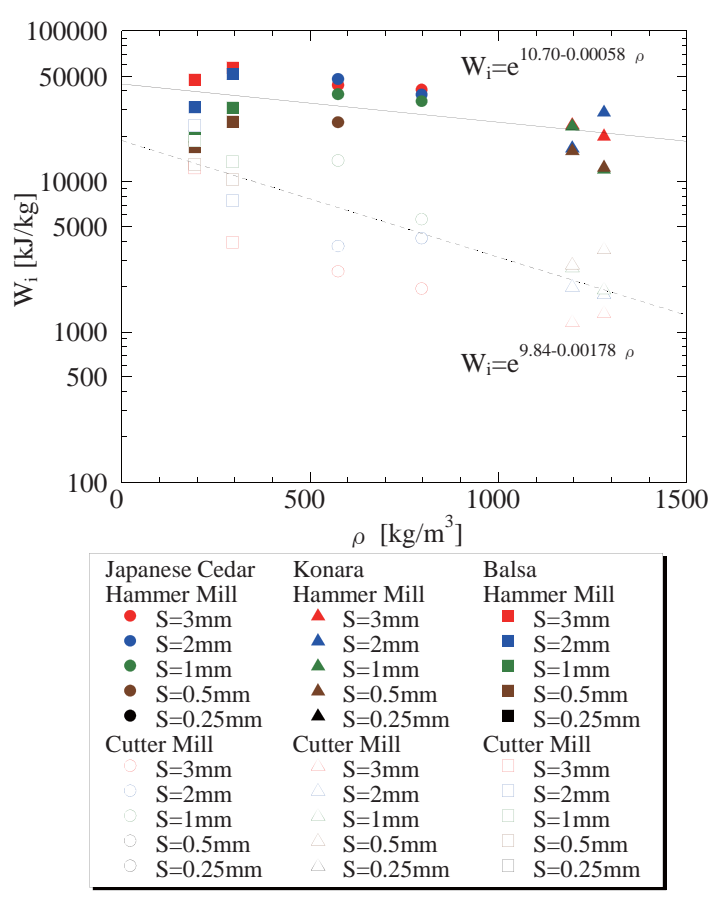

Fig.7 Empirical correlation of work index as a function of density

揮発分が放出され木材の繊維構造が崩壊し、質量が減少し ていくためである。しかしながら、Fig.11に示されている ように、熱分解温度上昇に伴う半炭化物の構造変化は樹種 により差異が認められる。 $\mathrm{T} \leqq 200{ }^{\circ} \mathrm{C}$ の熱分解が進行する

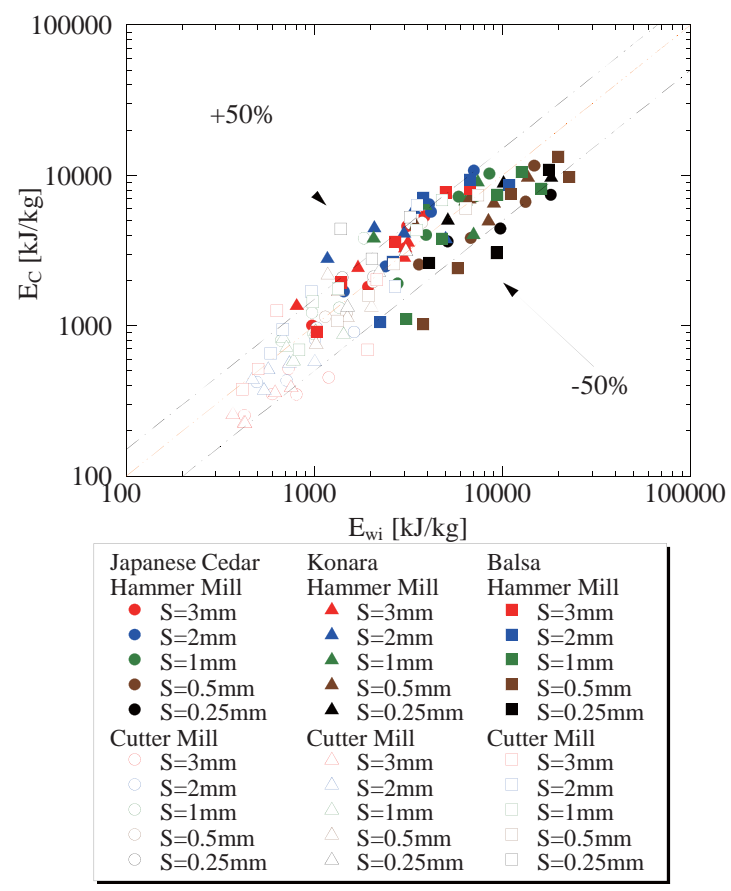

Fig.8 Comparison of experimental data with predicted data

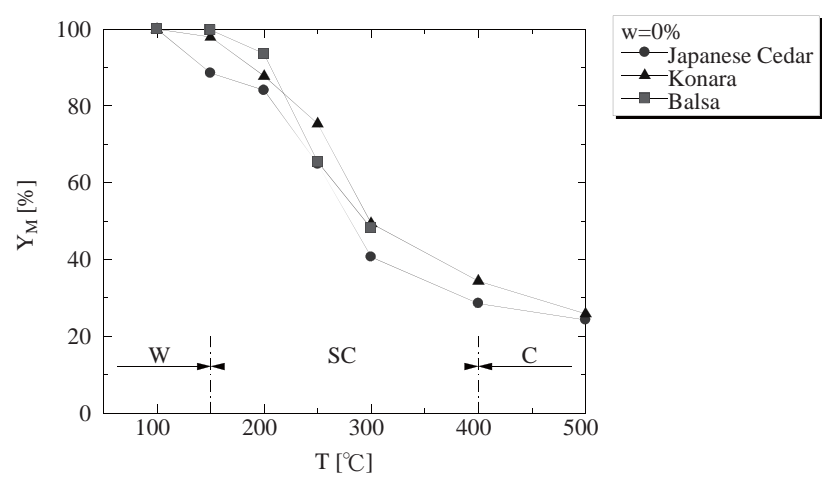

Fig.9 Mass yield of semi-carbonized charcoal

前段階では樹種の影響はないが、 $\mathrm{T}>200{ }^{\circ} \mathrm{C}$ の半炭化領域 ではバルサ材のみが急激に密度比が低下していることが見 て取れる。これは、スギ間伐材及びコナラ材は熱分解が進 み質量が減少すると同時に体積収縮が生じるのに対して、 バルサ材では体積収縮が生じていないためであると考えら れる。以上から、 $\mathrm{T}>200{ }^{\circ} \mathrm{C}$ に対するバルサ材は、スギ間 伐材とコナラ材とは性格を異にしていることがわかる。

3.2 .2 粉砕エネルギーに及ぼす樹種・半炭化・粉砕方式·

$$
\text { スクリーンの影響 }
$$

Fig.12 は半炭化処理したスギ間伐材、コナラ材、バルサ 材の粉砕エネルギー $\mathrm{E}_{\mathrm{C}}$ を熱分解温度 $\mathrm{T}$ に対して示したもの である。ただし、 $\mathrm{T}=100{ }^{\circ} \mathrm{C}$ は半炭化処理をしていない絶乾 


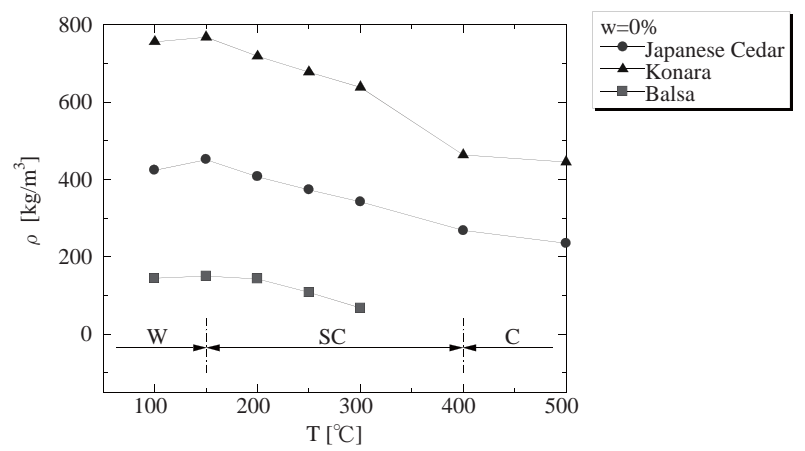

Fig.10 Variation of density with pyrolysis temperature

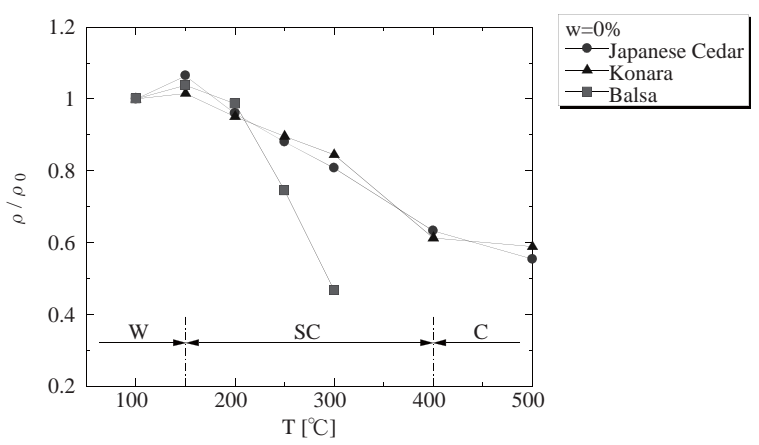

Fig.11 Ratio of semi-carbonized charcoal density to dry wood density

木材を表す。いずれの樹種および粉砕方式でも $\mathrm{T} \leqq 150{ }^{\circ} \mathrm{C}$ の $\mathrm{W}$ 領域において $\mathrm{E}_{\mathrm{C}}$ は高いが、 $200{ }^{\circ} \mathrm{C} \leqq \mathrm{T} \leqq 400{ }^{\circ} \mathrm{C}$ の $\mathrm{SC}$ 領域で $\mathrm{E}_{\mathrm{C}}$ は急激に減少し、 $\mathrm{T} \geqq 400{ }^{\circ} \mathrm{C}$ の $\mathrm{C}$ 領域ではかなり 小さな值となる。これは熱分解により木質繊維構造が破壊さ れたためと考えられる。W 領域では、粉砕方式による差異 が顕著であり、ハンマーミルではカッターミルに比べ 4 倍程 度の大きさとなっている。粉砕方式の差異に比べ、樹種の差 異はそれほど大きくはないが、ハンマーミルでは密度の高い コナラ材が、カッターミルでは密度の低いバルサ材が、他の 樹種に比べて高い值をとる。 SC 領域および C 領域では樹種 および粉砕方式とは無関係にほぼ同じ $\mathrm{E}_{\mathrm{C}}$ となる。

Fig.13 は半炭化処理したコナラ材の熱分解温度 Tに対す る粉砕エネルギー $\mathrm{E}_{\mathrm{C}}$ の変化をスクリーン $\mathrm{S}$ 別に示す。両 粉砕方式共に S が小さいほど $\mathrm{E}_{\mathrm{C}}$ は増大する。これは他の 樹種についても同様である。

3.2.3 Bondの法則による粉砕エネルギーの実験相関式

Fig.14 は各樹種・各粉砕方式で得られた粉砕仕事指数 $\mathrm{W}_{\mathrm{i}}$ を熱分解温度 $\mathrm{T}$ に対して示したものであり、図中のパラメー 夕は粉砕方式別に中塗の記号はハンマーミル、中抜きの記 号はカッターミル、記号の違いは樹種を、色の違いはスク リーンを表している。

$\mathrm{T} \leqq 200{ }^{\circ} \mathrm{C}$ の領域では樹種、スクリーンによらず粉砕方

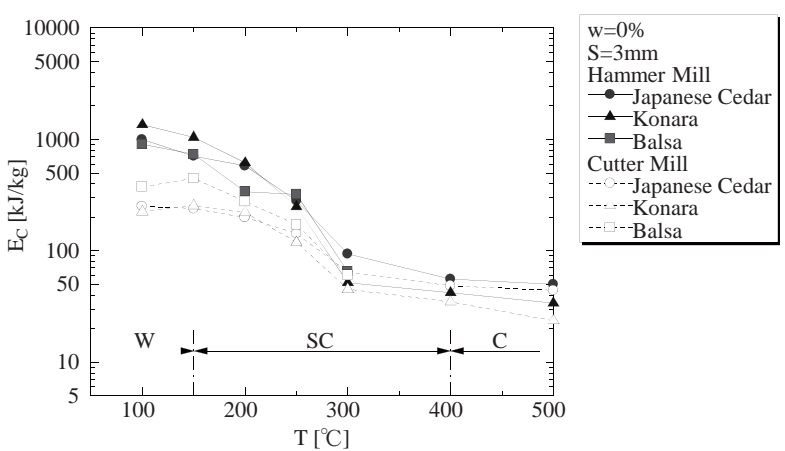

Fig.12 Effect of tree species and pyrolysis temperature of woody biomass on comminution energy

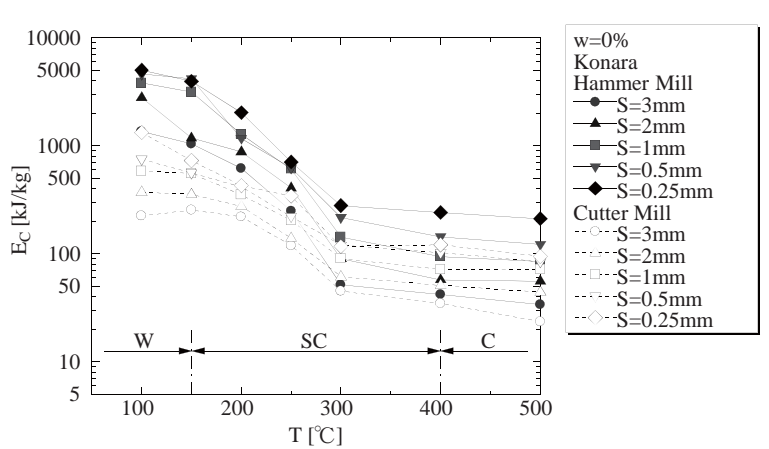

Fig.13 Effect of pyrolysis temperature of woody biomasson comminution energy

式別に式 (7)（図中実線）、式 (8)（図中破線）に示す実験相 関式が得られた。 $\mathrm{T}>200{ }^{\circ} \mathrm{C}$ の領域では樹種、スクリーン、 粉砕方式によらず、 $\mathrm{W}_{\mathrm{i}}$ を式 (8) に示す $\mathrm{T} \leqq 200{ }^{\circ} \mathrm{C}$ のカッター ミルに対する実験相関式で与えることができる。

$W_{i}=e^{9.67-0.01041 T}$

for Hammer mill in $\mathrm{T} \leqq 200{ }^{\circ} \mathrm{C}$

$W_{i}=e^{8.14-0.00693 T}$

for Hammer mill in $\mathrm{T}>200{ }^{\circ} \mathrm{C}$

for Cutter mill

なお、バルサ材は Fig.11で示したように T > $200{ }^{\circ} \mathrm{C}$ の領 域で他の樹種と特性が異なるため、いずれの粉砕方式にお いても式 (9)（図中一点鎖線）に示す実験相関式を与える。

$W_{i}=e^{15.03-0.03495 T}$

for Hammer mill and Cutter mill in $\mathrm{T}>200{ }^{\circ} \mathrm{C}$

式 (7)、(8)、(9)に示した $\mathrm{W}_{\mathrm{i}}$ の実験相関式より算出した 粉砕エネルギーの予測值 $\mathrm{E}_{\mathrm{Wi}}$ を粉砕エネルギーの実験值 $\mathrm{E}_{\mathrm{C}}$ と比較した。比較結果を Fig.15に示す。 $\mathrm{W}_{\mathrm{i}}$ の実験相関式 を用いることで、 $\pm 60 \%$ の範囲で粉砕エネルギーの実験值 を予測することができる。 


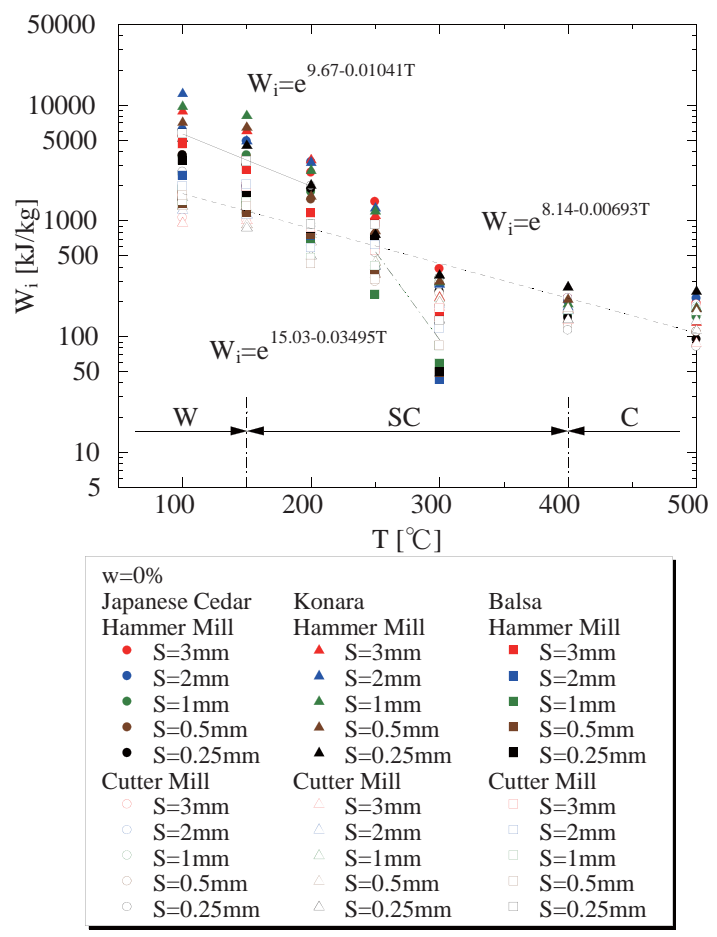

Fig.14 Empirical correlation of work index as a function of pyrolysis temperature

\section{4. 結 言}

里山に賦存する代表的な広葉樹である高密度のコナラ 材、森林バイオマスの代表的な針葉樹であるスギ間伐材、 木材資源の中で最も密度の低いバルサ材を対象に、粉砕物 燃料製造のプロセスエネルギー評価において重要となる粉 砕特性を検討した結果、以下の結論が得られた。

(1) 未改質木質バイオマスの粉砕エネルギー

Bondの法則における粉砕仕事指数は、繊維飽和点以下 の含水率では含水率の関数として、繊維飽和点以上の含水 率では粉砕エネルギーを密度の関数として表現することに より、樹種に関係なく粉砕方式別に実験相関式を与えるこ とができた。本研究で提案した粉砕仕事指数の実験相関式 と粉砕実験結果を比較すると $\pm 50 \%$ の範囲内で粉砕エネル ギーを見積もることができる。

(2) 半炭化木質バイオマスの粉砕エネルギー

Bond の法則における粉砕仕事指数は、 $\mathrm{T} \leqq 200{ }^{\circ} \mathrm{C}$ の領域 では 3 樹種に関係なく、粉砕方式別に実験相関式を与える ことができた。 $\mathrm{T}>200{ }^{\circ} \mathrm{C}$ の領域ではスギ間伐材とコナラ 材の両樹種は、粉砕方式に依存せず 1 つの実験相関式を与 えることができた。 T>200 ${ }^{\circ} \mathrm{C}$ の領域におけるバルサ材に 関しては他の樹種と特性が異なるため、他の樹種とは異な る実験相関式となった。本研究で提案した粉砕仕事指数の 実験相関式と粉砕実験結果を比較すると $\pm 60 \%$ の範囲内 で粉砕エネルギーを見積もることができる。

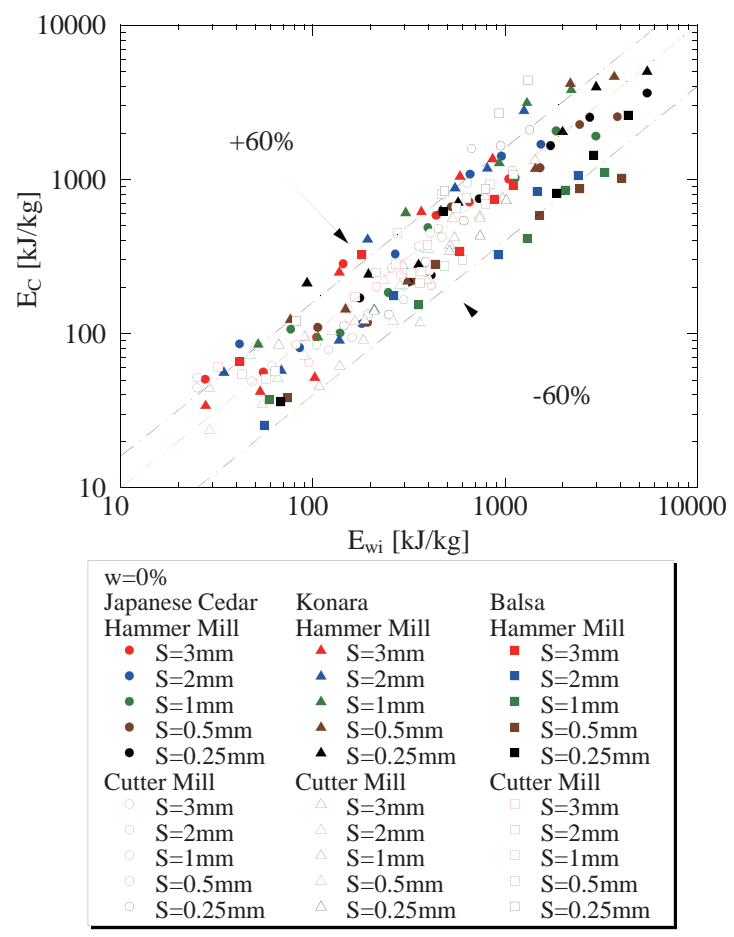

Fig.15 Comparison of experimental data with predicted data

\section{参考文献}

1) 経済産業省・資源エネルギー庁：“再生可能エネルギーの固定 価格買取制度”、(2012)

2) 農林水産省：“バイオマスニッポン総合戦略”、(2006)

3) 農林水産省：“森林・林業再生プラン”、(2009)

4) 内閣官房国家戦略室：“新成長戦略〜「元気な日本」復活のシ ナリオ〜”、(2010)

5) 環境省自然環境局：“日本の里地里山の調査・分析について（中 間報告)”、(2001)

6) 佐野寬、本庄孝子、井田民男：“エネルギー自立性を高める新 里山システム”、日本エネルギー学会誌 85-1（2006）42-48

7) 環境省 : “SATOYAMA イニシアティブ”、(2011)

8）西健治、澤井徹、大政光史、廣川敬康、渋江唯司、梶本武志: “木 質系粉砕物燃料の前処理工程（粉砕・乾燥・半炭化改質）お よび輸送に抢けるエネルギー消費量の低減”、高温学会誌 37-2 (2011) 63-70

9) 林野庁計画課：“森林資源現況調査”、(2007)

10）椿淳一郎、鈴木道隆、神田良照：“入門粒子・粉体工学”、日 刊工業新聞社、(2002) 113

11）森林総合研究所：“改訂 4 版木材工業ハンドブック”、丸善株 式会社、(2004) 113-114

12）池際博行、平田重俊、平岡健志、梶本武志：“木材の簡易炭化 法と低温炭化処理木材の性質”、木材学会誌 41-5（1995）516521 